\title{
Recent Developments of Flexible CdTe Solar Cells on Metallic Substrates: Issues and Prospects
}

\author{
M. M. Aliyu, ${ }^{1}$ M. A. Islam, ${ }^{1}$ N. R. Hamzah, ${ }^{1}$ M. R. Karim, ${ }^{2}$ M. A. Matin, ${ }^{1}$ \\ K. Sopian, ${ }^{3}$ and N. Amin ${ }^{1,2,3}$ \\ ${ }^{1}$ Department of Electrical, Electronic and Systems Engineering, Faculty of Engineering and Built Environment, \\ Universiti Kebangsaan Malaysia (UKM), Selangor, 43600 Bangi, Malaysia \\ ${ }^{2}$ Center of Excellence for Research in Engineering Materials (CEREM), College of Engineering, King Saud University, \\ Riyadh 11421, Saudi Arabia \\ ${ }^{3}$ Solar Energy Research Institute (SERI), Universiti Kebangsaan Malaysia (UKM), Selangor, 43600 Bangi, Malaysia
}

Correspondence should be addressed to N. Amin, nowshad@eng.ukm.my

Received 24 September 2011; Revised 11 November 2011; Accepted 14 November 2011

Academic Editor: Raghu N. Bhattacharya

Copyright () 2012 M. M. Aliyu et al. This is an open access article distributed under the Creative Commons Attribution License, which permits unrestricted use, distribution, and reproduction in any medium, provided the original work is properly cited.

\begin{abstract}
This study investigates the key issues in the fabrication of CdTe solar cells on metallic substrates, their trends, and characteristics as well as effects on solar cell performance. Previous research works are reviewed while the successes, potentials, and problems of such technology are highlighted. Flexible solar cells offer several advantages in terms of production, cost, and application over glassbased types. Of all the metals studied as substrates for CdTe solar cells, molybdenum appears the most favorable candidate, while close spaced sublimation (CSS), electrodeposition (ED), magnetic sputtering (MS), and high vacuum thermal evaporation (HVE) have been found to be most common deposition technologies used for CdTe on metal foils. The advantages of these techniques include large grain size (CSS), ease of constituent control (ED), high material incorporation (MS), and low temperature process (MS, HVE, ED). These invert-structured thin film CdTe solar cells, like their superstrate counterparts, suffer from problems of poor ohmic contact at the back electrode. Thus similar strategies are applied to minimize this problem. Despite the challenges faced by flexible structures, efficiencies of up to $13.8 \%$ and $7.8 \%$ have been achieved in superstrate and substrate cell, respectively. Based on these analyses, new strategies have been proposed for obtaining cheaper, more efficient, and viable flexible CdTe solar cells of the future.
\end{abstract}

\section{Introduction}

Polycrystalline thin film solar cells have been recognized as important source of low-cost, clean, environment-friendly energy of the future. However, the full exploration of these photovoltaic $(\mathrm{PV})$ devices requires increased development and improvement of cell performances through better understanding of cell behavior, material usage, and simpler and cheaper industrial processes. Among the thin film semiconductors, CdTe has shown high potentials as a good solar cell absorber, due to its direct, ideal bandgap $(1.45 \mathrm{eV})$ for solar absorption, high absorption coefficient, low-cost, and multiple fabrication technologies, coupled with its high chemical stability [1]. Conventional CdTe solar cells have been fabricated on glass substrate using up to 14 methodologies, [2], with CSS giving the highest efficiency of $17.3 \%$ [3], from a projected theoretical maximum efficiency of nearly $30 \%$ [4]. In conventional CdTe solar cells, glass makes up to $98 \%$ of the device thickness and weight [5]. But glass is known to be heavy, fragile, and rigid, requiring extra care and substantial support for fabrication and installation, leading to additional overall expenses. Its poor thermal expansivity and conductivity cause thermal gradients and nonuniform device properties on panels in continuous fabrication processes involving high temperatures $\left(>500^{\circ} \mathrm{C}\right)$. These characteristics make high temperature processing difficult and expensive $[2,6-9]$. Due to their very low specific power $(\mathrm{kW} / \mathrm{kg})$, glassbased solar modules are cumbersome in space applications with increased deployment difficulties resulting in additional costs, running into tens of millions of dollars [10]. 
These problems can be eliminated or at least minimized if flexible substrates such as metallic foils or polymers are used in place of glass. Thin film solar cells such as CdTe can be fabricated on thin foils of metals or polymers, resulting in a flexible structure with several advantages. Such foil-based solar cells can be manufactured in a roll-to-roll process that offers several manufacturing advantages such as lower equipment size (up to 30 times smaller), thus lower costs, higher material utilization, increased fabrication scalability, and high speed of deposition [11]. Flexible solar cell manufacture may not need the expensive robotics for heavy and fragile glass, implying simpler equipment, cheaper modules, lower energy payback time, and lower investment in equipment and infrastructure [10]. The high specific power of more than $2 \mathrm{~kW} / \mathrm{kg}$ achievable by flexible solar cells makes their potential space applications very attractive [12]. Moreover, it is known that high energy particles and radiation in outer space degrade solar cells by changing the structural, electrical, and optical properties of the cells [13]. But studies have shown that CdTe solar cells have the highest stability to particle irradiation, and for metallic substrates, they do not show the "darkening" color exhibited by some glass-based cells thus, making them potentially better suited for space applications [13-18]. The development of smaller, lightweight consumer electronics, such as voice/data communication, health monitoring, emergency, and surveillance devices increases the need for simple, cheap, and portable power supply systems, which flexible solar cells can provide. Concepts such as clothintegrated solar modules are all compatible with flexible cells, since they do not cause discomfort to user [19]. In fact, smart clothes technology is limited by the availability of suitable flexible modules [20]. Flexible solar cell technology can equally fit, seamlessly, with the so-called plastic electronics, where printed circuits and devices are produced on flexible substrates [21]. Another area of flexible PV applications is in Building Integrated Photovoltaic (BIPV) where solar modules are increasingly required to be flexible and lightweight in order to integrate into existing building fabrics, tents, sails, glass, and all sort of surfaces and shapes [21].

This paper investigates the recent and current developments of research results of flexible CdTe solar cells deposited on metallic substrates. Different deposition methodologies, fabrication conditions and processes as well as typical performance indices are highlighted, while the successes and shortcomings of the technology have been assessed, and proposals are presented for future research focus that may lead to higher performance and cheaper modules.

\section{Superstrate and Substrate Structures in Thin Film Solar Cells}

Thin film solar cells can generally be developed in two structures, known as superstrate and substrate, depending on the direction through which light enters the cell. In superstrates, the light enters the cell through the substrate base, on which the cell layers were deposited. For substrate structures however, the light does not pass through the base, but rather from the opposite side, as shown in Figure 1. Thus, for superstrate cells, the supporting substrate must be reasonably

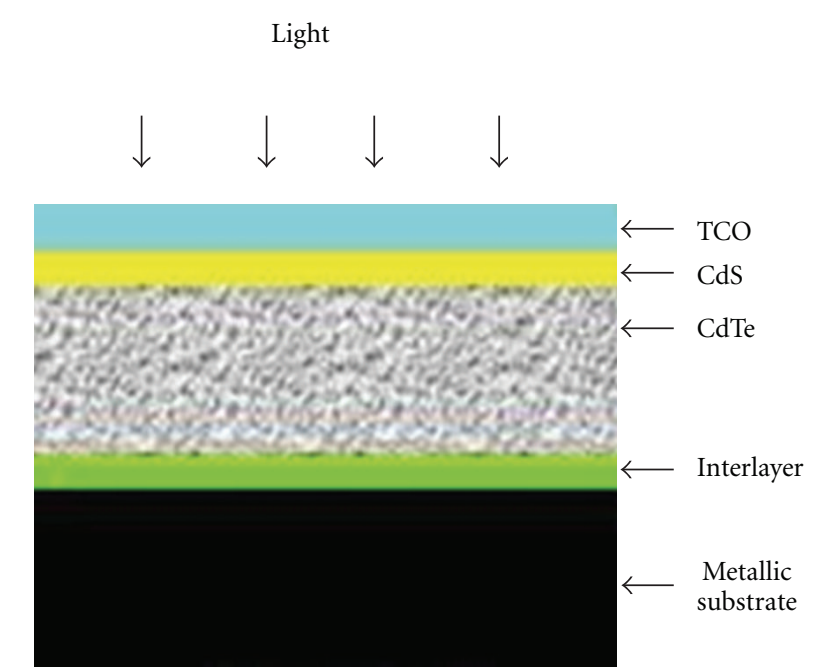

(a) substrate

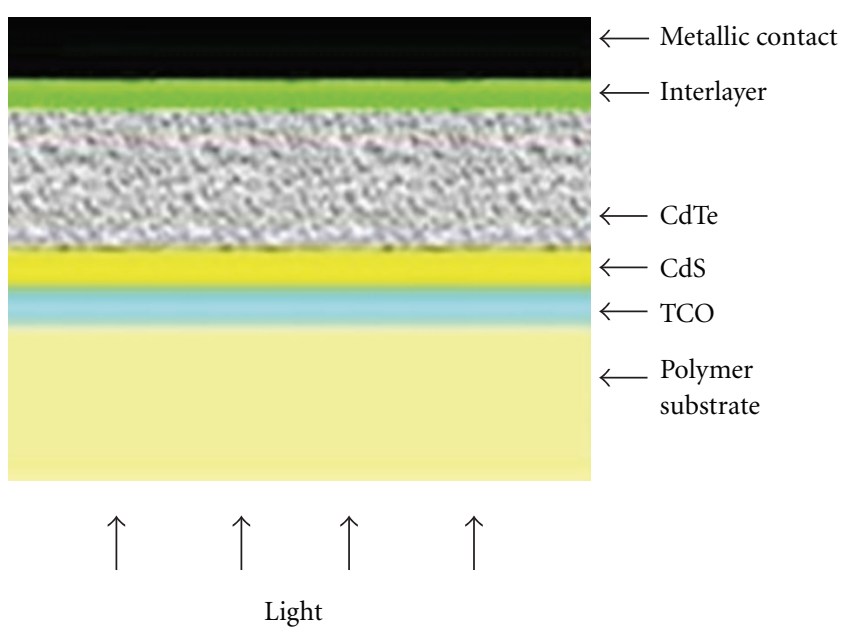

(b) superstrate

FIGURE 1: Substrate and superstrate structures for flexible CdTe solar cells.

transparent, as to allow enough light pass into the cell; most CdTe solar cells have been deposited on this structure [22]. Whereas metallic substrates can only be used in the substrates structure due to their opacity, polymers may be deposited in both structures, depending on their transparency [23].

To date, the highest reported efficiency in flexible CdTe solar cells of $13.8 \%$ was achieved with superstrate structure using thin polyimide while the highest efficiency in substrate on polyimide is $7.3 \%$ and on metallic foils is 7.8\% [25-28]. It is believed that superstrate configuration generally produces higher efficiency than substrates in CdTe solar cells [23]. The reasons being that in substrate cells, the $\mathrm{CdCl}_{2}$ treatment can only be applied to the CdS or both CdS and CdTe layers. In the first case, the CdTe crystallinity is not optimized while in the latter, $\mathrm{CdCl}_{2}$ treatment tends to diffuse impurities to the ohmic contact, changing its properties. In both cases, the interdiffusion is difficult to control $[5,29,30]$. In addition, while in superstrate cells, the back contact layer is 
last, after the high-temperature $\mathrm{CdCl}_{2}$ treatment, in substrate structure, it is the first stage, thus subsequent high temperature processes may cause diffusion problems. It is also not possible, in the substrate cells, to carry out etching process on the CdTe layer, prior to back contacts formation $[27,31]$. However, substrate structures are of interest because the CdTe-CdS interface is not buried under the thick CdTe layer, providing access for its morphological studies [32]. Several materials have been used as substrates for the deposition of CdTe to produce flexible solar cells, each with its own advantages and shortcomings. However, the ones that have received most attention among metals are molybdenum (Mo), titanium (Ti), and stainless steel (SS) while among polymers, are polyimide (PI), polyethylene terephthalate (PET), and polyethylene naphthalate (PEN) $[5,7,8,12,25,28,33,34]$. Polymer substrates allow for the fabrication of both superstrate and substrates structures, and to date, they produce the highest efficiency of flexible CdTe solar cells [25]. However, commercially available transparent polymers, such as polyimide are not stable at such high temperatures. The polyimide films such as Kapton and Upilex can withstand high temperatures $\left(450^{\circ} \mathrm{C}\right)$, but they are dark yellow and they strongly absorb visible radiation, and hence cells fabricated on such polyimide films will yield limited current due to optical absorption [5, 22, 35-38]. One of the strategies employed to minimize this problem is by reducing the polyimide thickness, thereby reducing the optical absorption by the PI. In place of the about $50-125 \mu \mathrm{m}$ commercial PI, typical values of $7.5-12 \mu \mathrm{m}$ have been reported to give higher cell performance.

However, just recently, Dupont introduced the new Kapton colorless polyimide film which had both the tolerance for high temperatures needed and higher light transmittance due to its transparency, which helped in producing the new record efficiency of polymer-based solar cells $[25,39]$. Another challenge of flexible substrates is poor film adhesion to substrates and the need for special contacting techniques between $\mathrm{CdTe}$ and the foil. However, of all the metal foils reviewed, Mo is most attractive due to its matched thermal expansivity to that of CdTe, given as $4.8 \times 10^{-6} \mathrm{~K}^{-1}$ $(\mathrm{CdTe})$ and $5.0 \times 10^{-6} \mathrm{~K}^{-1}$ (Mo). Thus, even at annealing temperatures of $550^{\circ} \mathrm{C}$, CdTe films neither peel off nor form blisters or bubbles $[6,8,40-42]$. Also, because Mo can be obtained in high purity, problems of dopant impurities diffusing into the CdTe at elevated temperatures are reduced. In addition the ready availability of pure Mo reduces the possibility of dopant impurities diffusing into the CdTe at elevated temperatures, as it occurs in other substrates, such as stainless steel (SS) [32, 43, 44].

One of the greatest challenges in CdTe solar cell fabrication is the issue of back contacting techniques. The relatively high electron affinity $(4.5 \mathrm{eV})$ of p-CdTe normally produces a rectifying, nonohmic, or Schottky junction with the metal electrode, leading to reduced $V_{\mathrm{oc}}$ and overall lower cell performance. In order to reduce this defect, an equally high work function metal is required as back contact However, most metals do not have the required high work function to overcome this potential. Thus, the p-CdTe is heavily doped, thereby reducing the potential barrier making tunneling possible across the junction. Alternatively, a lower work function, and heavily doped p-type semiconductor is placed between the CdTe and metallic contact, serving as an interlayer. Such measures, referred to as back surface field (BSF) increases cell performance by reducing the recombination at the back contact, leading to improved $V_{\text {oc }}$ and reduced series resistance $[44,46]$. Some commonly used metals and semiconductors, either alone or in combination with others (especially $\mathrm{Cu}$ ), as back contact layers on glass include $\mathrm{C}: \mathrm{Cu}, \mathrm{Cu}, \mathrm{Au}, \mathrm{Ag}, \mathrm{Sb}, \mathrm{Ni}, \mathrm{Mo}, \mathrm{Te}, \mathrm{ZnTe}, \mathrm{Sb}_{2} \mathrm{Te}_{3}$, $\mathrm{As}_{2} \mathrm{Te}_{3}, \mathrm{CuTe}$, and HgTe, [6, 12, 24, 26, 29, 32, 44, 47-49] When some of these were used in flexible cells, improved cell performances were observed.

\section{Some Commonly Reported Deposition Methodologies for Flexible CdTe Solar Cells}

3.1. Close-Spaced Sublimation (CSS). The CSS method is considered one of the most successful methods in developing CdTe thin films due to its short deposition time, large grain size, high material utilization, and economical experimental facilities $[1,24,38]$. Moreover the highest efficiency and cheapest solar cells have been fabricated using this method $[3,50]$. Industrial production of these cells is currently carried out by First Solar using this method [51]. CSS is a high temperature $\left(400-670^{\circ} \mathrm{C}\right)$ process, and CdTe has been deposited on Mo using this method resulting in films of uniform, well-faceted grains, the size of order of film thickness [6]. For films deposited on both Mo and SS, grain sizes increases with substrate temperature, and grain sizes of about 3-6 $\mu \mathrm{m}$ of as-deposited films were obtained, while the usual $\mathrm{CdCl}_{2}$ is carried out in order to improve device characteristics such as $V_{\text {oc }}$ and FF [6, 7]. While stress increases with sublimation temperature, preferential orientation and lattice parameter decrease with increasing temperature. By using $\mathrm{Au}$ and Pd interlayer between Mo and CdTe, Mathew [6, 24, 47] reported reduced contact resistance. In addition there were differences in the surface roughness and grain sizes for films deposited on $\mathrm{Mo} / \mathrm{Au}$ and $\mathrm{Mo}$; films on $\mathrm{Mo} / \mathrm{Au}$ are larger than those on Mo, as in Figure 2. The resistivity of the two films as function of temperature was found to be minimum at $520^{\circ} \mathrm{C}$. The study showed that using $\mathrm{Au}$ as an interlayer between Mo and CdTe improves both the morphology and electrical characteristics of the films. Annealing the deposited films in air at $400^{\circ} \mathrm{C}$ showed better optoelectronic properties of the films [48]. This was in accord with the results of similar work carried out by Enríquez et al. [42], where both $J_{s c}$ and $V_{\text {oc }}$ of their cells were maximum for films annealed at $400^{\circ} \mathrm{C}$. Using CSS, Singh and Mcclure [41] also deposited CdTe on Mo substrates and demonstrated a model for the manufacture of a solar cell module on a large molybdenum foil substrate where the ITO layer is used as a means of series connection of individual cells. In addition, they showed that a higher $V_{\text {oc }}(824 \mathrm{mV})$ is achieved if two CdS layers (separated by air annealing) are used instead of a single CdS layer. Even though CSS has many advantages from the point of view of process time and the photovoltaic performance of the devices, it imposes restrictions on the choice and applicability of interlayer because at high temperatures 

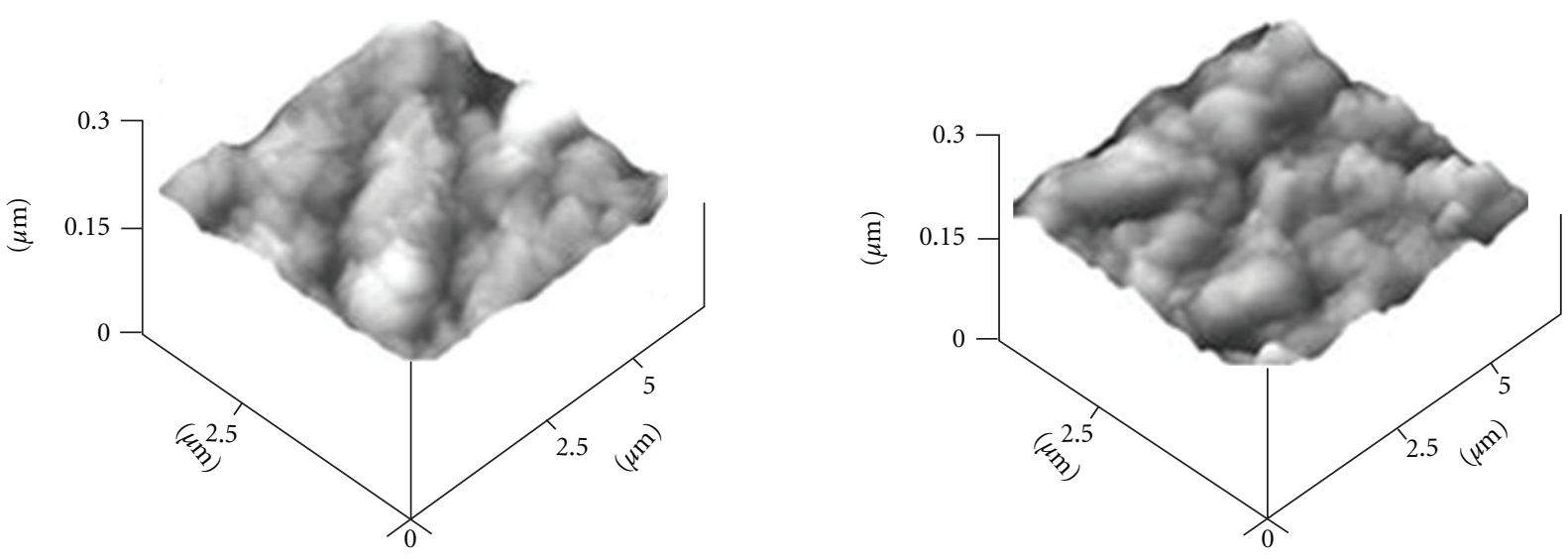

(a) CdTe films on Mo
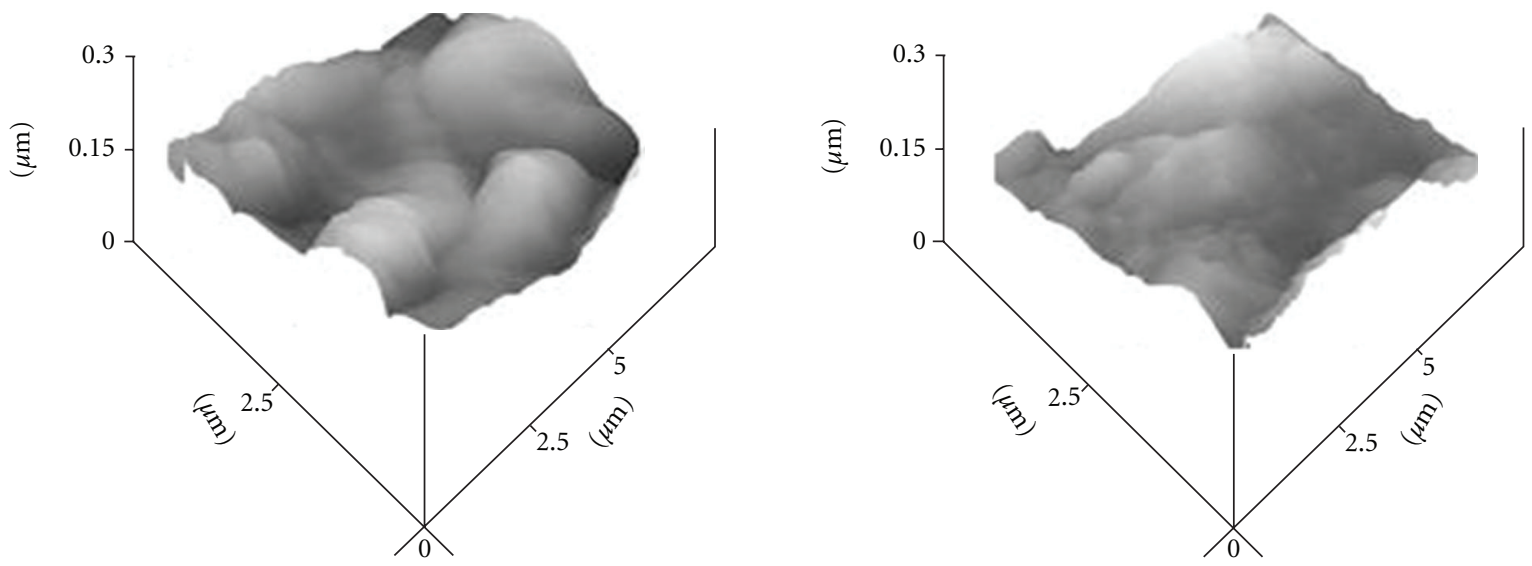

(b) CdTe films on $\mathrm{Mo} / \mathrm{Au}$

Figure 2: As-deposited and postannealed CdTe films grown on (a) Mo/Au and (b) Mo [24].

the interlayer may diffuse or decompose and may not remain suitable for back contacting purpose. However, this method is still considered as an economic and efficient method of deposition.

3.2. Electrodeposition (ED) of Flexible CdTe Solar Cells. Electrodeposition is a simple, economic and successful, thus attractive method for preparing large-area thin films, on both glass and metallic substrates, with several reported results of electrodeposited CdTe films [40, 45, 47, 52, 53]. The technique has good material utilization since deposition takes place on the substrates only, unlike most other techniques such as CSS and sputtering where deposited material is difficult to control. The ED of CdTe on metallic substrates is easier and faster than that on the ITO or ITO/CdS substrates. Uniform CdTe films can be easily deposited and the composition of the deposit can be controlled by varying the deposition potential $[47,54,55]$. In superstrates, this method can be utilized, in place of the bromine etching, to develop a thin Te-rich layer for the metallic contact deposition between the p-CdTe and the substrate. The first electrodeposited heterojunction $\mathrm{CdTe} / \mathrm{CdS}$ solar cell was developed in the early 1980s [56]. Later on BP Solar took over a leading position to scale up and improve the techno- logy for industrial production [38]. ED has been used for CdTe deposition on both SS and Mo using various potentials $(-570$ to $-590 \mathrm{mV},-1050$ to $-1070 \mathrm{mV})$ at temperatures of $80-85^{\circ} \mathrm{C}$, resulting in good stoichiometric films with compact morphology and good crystallinity, with (111) preferred orientations. Grain sizes of $0.2-0.4 \mu \mathrm{m}$ were achieved with $\mathrm{Cd}$ : Te composition ratio of $0.8446-1.0648$, which was found to depend on the deposition potential. Different characterization tools have been employed in understanding the properties of deposited CdTe films on metallic substrates. These include XRD/EDAX, SEM, TEM, Auger, Variable Angle Spectroscopic Ellipsometry (VASE), $I-V / C-V$, and Electron Probe Micro-Analyzer (EPMA). Results from characterization show that annealing has significant effects on the films properties. The average grain size, D, preferred directions and their relative intensities of preferred orientation $\left(I_{111} / I_{311}\right)$, lattice parameter (a), and stress all change with annealing time, while the compositional ratio of Cd to Te depends on the deposition potential [52]. The refractive indices and extinction coefficients of $\mathrm{CdTe}$ on $\mathrm{Mo}$ and SS have been compared to that of crystal CdTe and found that films on Mo and SS have similar optical behaviors to that of pure CdTe crystal (Figure 3). 


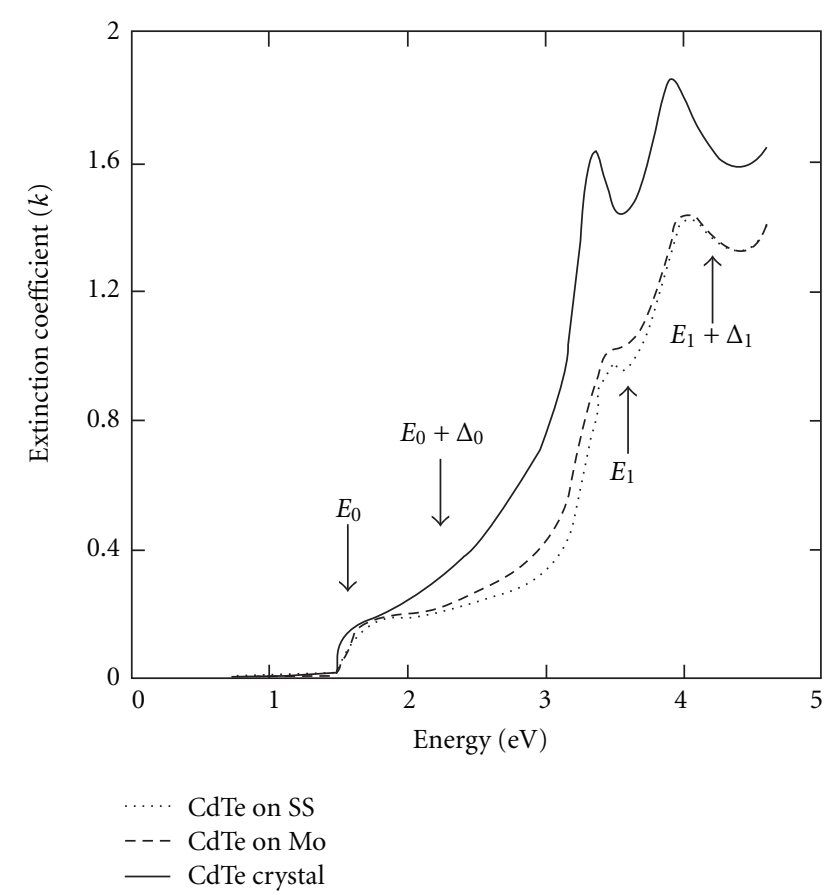

Figure 3: Extinction coefficient of CdTe films on various substrates [45].

\subsection{High Vacuum Thermal Evaporation (HVE) of Flexible} CdTe Solar Cells. Thermal evaporation is an attractive technique for simple inline deposition of large-area CdTe solar modules on both glass and flexible substrates, thus, making roll-to-roll manufacturing of flexible solar modules feasible [22]. Using evaporation temperatures of $220-300^{\circ} \mathrm{C}, \mathrm{CdTe}$ films of uniform grain size with preferred (111) were obtained $[8,9,17,41,46,57]$. The growth and morphology of CdTe depends strongly on the substrate on which it is grown. As shown in Figure 4, the as deposited CdTe layer on Mo is compact with grain size of $0.5 \mu \mathrm{m}$ to $2 \mu \mathrm{m}$. The morphology is rough due to irregular shape and size of grains and is similar to the as deposited CdTe on CdS/FTO/glass, even if in this later case the shape and size of grains are more randomly distributed.

After $\mathrm{CdCl}_{2}$ treatment, the $\mathrm{CdTe}$ layer on $\mathrm{Mo} /$ glass has grains with well-defined shape but different grain size ranging from $3 \mu \mathrm{m}$ to $10 \mu \mathrm{m}$. $\mathrm{CdCl}_{2}$ treated $\mathrm{CdTe}$ on $\mathrm{CdS} /$ FTO/glass is very different, with grains of random shape and size of $1 \mu \mathrm{m}$ to $10 \mu \mathrm{m}$ [46]. In another comparative study, Chandramohan et al. [9] investigated the structural properties of CdTe on different substrates; SS, Mo, and glass. They found that the crystallinity of the CdTe films depends on the film thickness and type of substrates, as given in Figure 5. For glass and SS, at thickness of $235 \mathrm{~nm}$, the films showed no preferred orientation, whereas for Mo, the (111) direction completely disappeared, instead, (106) became very distinct.

In a related work, Singh et al. [8] showed that annealing temperature, time, atmosphere, and $\mathrm{CdCl}_{2}$ treatment have profound effects on the properties of the CdTe. Using $\mathrm{Cu}-$ Te interlayer, they found that the film resistance decreased with thickness, leading to a cell with efficiency of $5.3 \%\left(J_{\mathrm{sc}}=\right.$ $22.0 \mathrm{~mA} / \mathrm{cm}^{2}, V_{\mathrm{oc}}=629 \mathrm{mV}$ and $\left.\mathrm{FF}=0.38\right)$ as in Figure 6.

3.4. Magnetron Sputtering of CdTe Solar Cells. Magnetron sputtering has the advantage of high material incorporation and low temperature process. Thus, in the substrate structure, the CdTe-CdS junction of such cells does not suffer from the high temperature interdiffusion. A feature of magnetron sputtering is that since the sputtered material is passed into the vapor phase by a physical momentum-exchange process, rather than a chemical or thermal process, virtually any material is a coating candidate [55]. Other advantages of sputtering are as follow: it is an entirely dry process, reactive doping can be carried at deposition, deposition rate is controlled, thus thickness is controlled and low energy ion bombardment in the plasma allows one to control lateral strain and morphology of grain boundaries [32]. DC guns, in the sputter machine, are generally used for sputtering conducting materials, such as metals, while an RF potential must be applied to the target when sputtering nonconducting materials [55]. Sputtered cells fabricated on metallic substrates have yielded reasonable performance parameters, having the best substrate efficiency of $7.8 \%$ $[26,27,31,43]$. Common variables of deposition are temperature, pressure, RF power, target-substrate separation, type, and gas flow rate.

Pressure variation affects the growth rate and grain boundaries; faster growth and compact grains were obtained at lower deposition pressure. Compaan and Karpov [27] investigated the performance of substrate cells by sputtering CdTe on glass, Mo and Mo-coated Kapton polyimide and CdS of various thicknesses. The cells exhibit fairly low QE (Figure 7) in the 400 to $500 \mathrm{~nm}$ region which is consistent with no $\mathrm{CdS}$ consumption ( $\mathrm{S}$ interdiffusion into $\mathrm{CdTe}$ or TCO) during $\mathrm{CdCl}_{2}$ treatment. This is in contrast to superstrate cells which showed better QE in the blue region than expected, based on the as-deposited CdS thickness. This arises from interdiffusion at the CdS/CdTe interface. The QE curves of substrate cells (Figure 7) with thicker CdS show little evidence of interdiffusion but the cell with thinner CdS shows a response similar to the superstrate cells [26]. The differences in the QE data lead to a conclusion that the presence of a CdS layer of more than about $100 \mathrm{~nm}$ thick inhibits interdiffusion during the $\mathrm{CdCl}_{2}$ treatment. This difference may result from the fact that the CdS is grown on fully formed CdTe grains rather than being adjacent to the smallgrain nucleation layer of CdTe.

The lack of accessibility of the back contact for proper treatment to promote tunneling by carriers in such cells is also a challenge. The interdiffusion problems at the CdTe/ $\mathrm{CdS}$ associated to optical absorption by the CdS layer, unlike the junction, leads to reduced quantum efficiency in superstrate structure where the CdS layer is thinned out by interdiffusion. Thus, while CdTe solar cells on glass have attained efficiencies of over 17\%, similar cells on metallic have a maximum efficiency of $7.8 \%$, to date. The reasons for this low efficiency include poor back contact between CdTe and metal foil. 


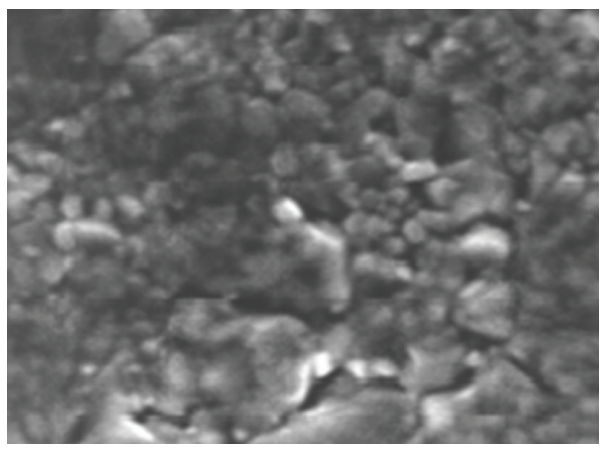

(a) $\mathrm{CdTe} / \mathrm{CdS} / \mathrm{FTO} /$ glass

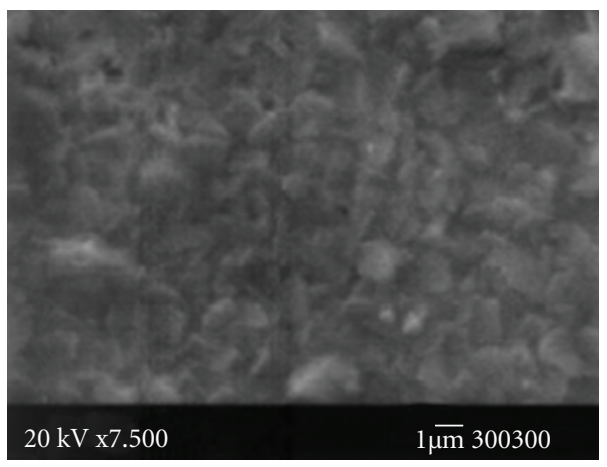

(c) $\mathrm{CdTe} / \mathrm{Mo}$

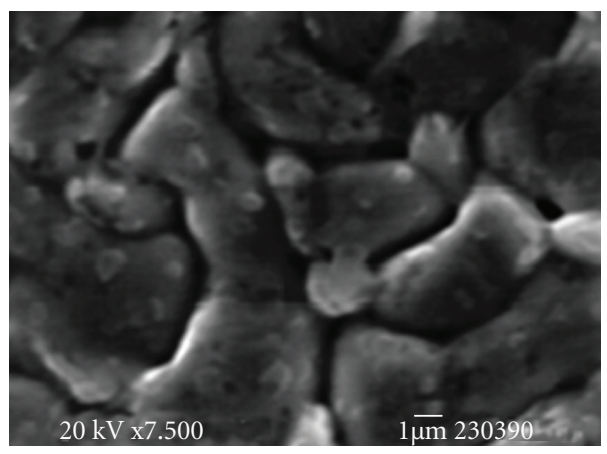

(b) $\mathrm{CdCl}_{2}$ treated

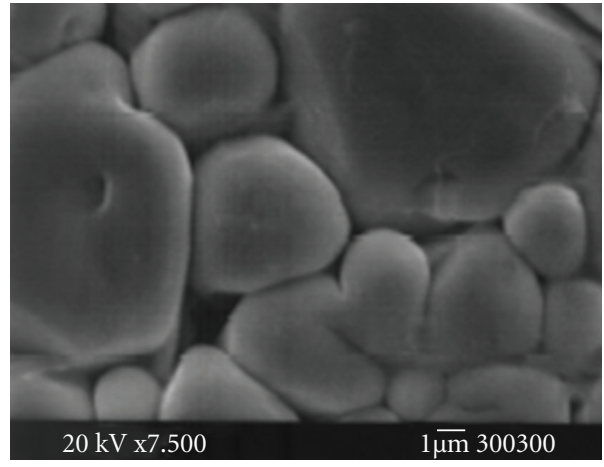

(d) $\mathrm{CdCl}_{2}$ treated

Figure 4: SEM of CdTe films showing effect of $\mathrm{CdCl}_{2}$ treatment for (a-b) glass and (c-d) Mo substrates, respectively [46].
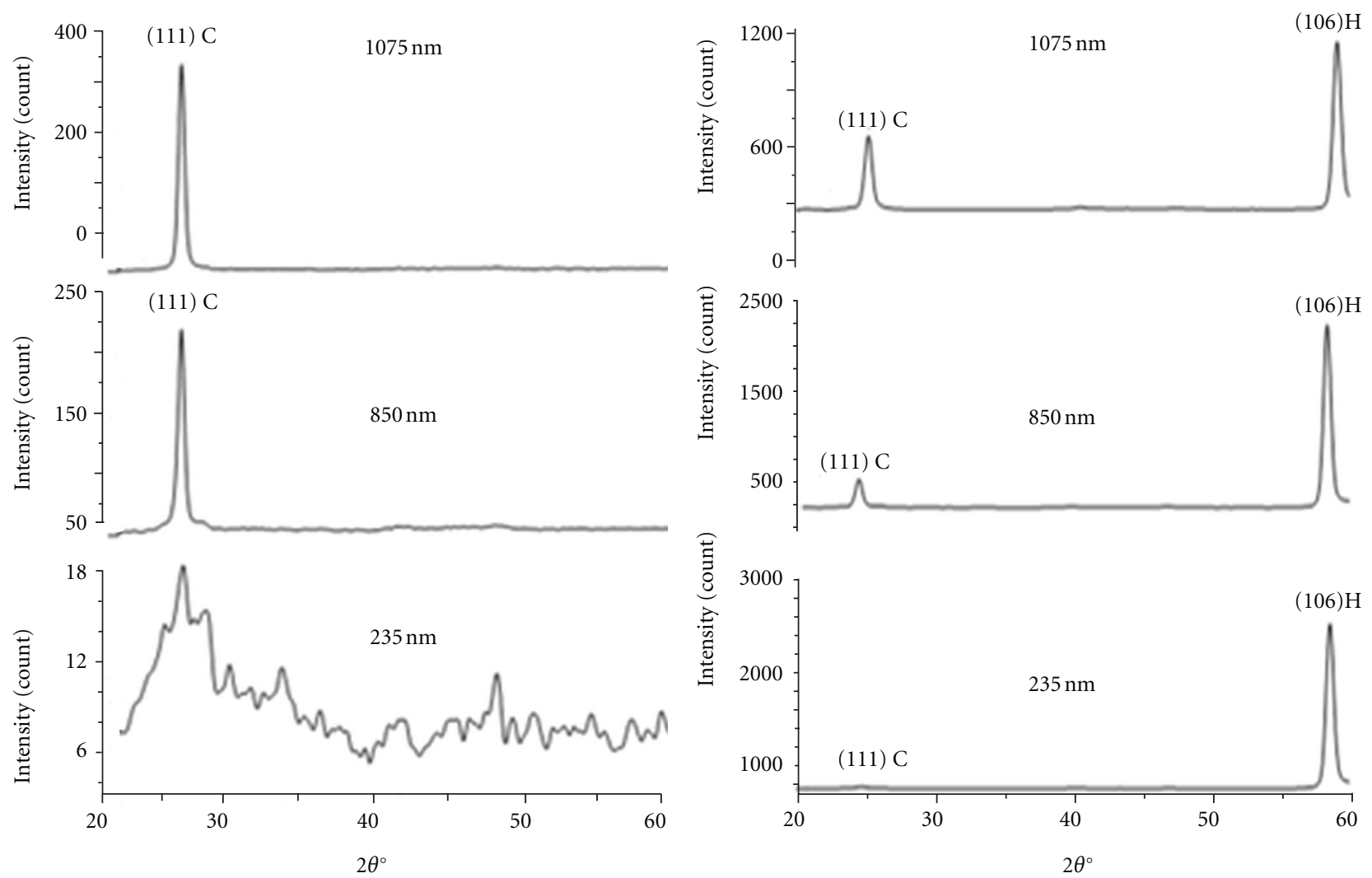

(a)

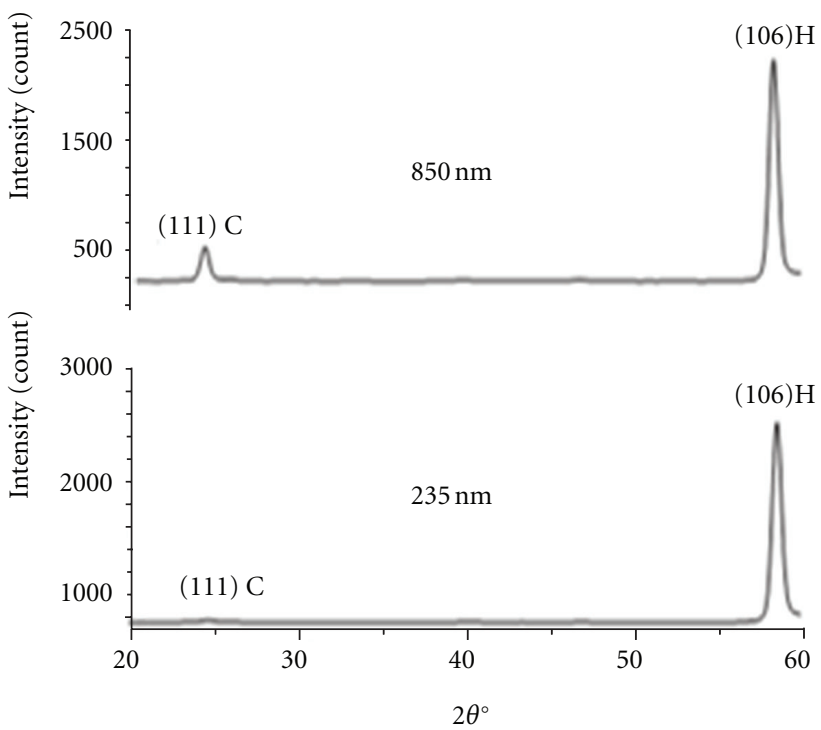

(b)

Figure 5: Crystallinity dependence on thickness for (a) glass and (b) Mo [9]. 
TABLE 1: Research trends in flexible CdTe cells on metallic foils with best polyimide sheets.

\begin{tabular}{|c|c|c|c|c|c|c|c|c|}
\hline & Group/year & $\begin{array}{l}\text { Deposition } \\
\text { method }\end{array}$ & $\begin{array}{l}\text { Highest } \\
\text { deposition } \\
\text { temp. }\left({ }^{\circ} \mathrm{C}\right)\end{array}$ & $\begin{array}{l}\text { Anneal } \\
\text { temp. } \\
\left({ }^{\circ} \mathrm{C}\right)\end{array}$ & $\begin{array}{c}\text { Back } \\
\text { contacts }\end{array}$ & $\begin{array}{c}\text { Front } \\
\text { contacts }\end{array}$ & $\begin{array}{c}\text { Best } \\
\text { efficiency }\end{array}$ & Ref. \\
\hline 1 & ETH Switzerland, 2000 & HVE & 300 & 430 & $\begin{array}{c}\mathrm{Te}-\mathrm{Mo} \\
\mathrm{Sb}_{2} \mathrm{Te}_{3}-\mathrm{Mo}\end{array}$ & $\mathrm{AZO}$ & $2 \%$ & {$[46]$} \\
\hline 2 & UNAM Mexico, 2004 & CSS & 670 & 400 & $\mathrm{Au}-\mathrm{Pd}$ & ITO & $3.5 \%$ & {$[42]$} \\
\hline 3 & Univ. of Kentucky, 2003 & HVE & 220 & $300-500$ & $\mathrm{Cu}-\mathrm{Te}$ & ITO/AZO & $6 \%$ & {$[41]$} \\
\hline 4 & Univ. of Toledo, 2005 & MS & 220 & 387 & Mo & $\mathrm{AZO}$ & $6.6 \%$ & {$[26,31]$} \\
\hline 5 & Univ. of Toledo, 2005 & MS & 260 & 390 & $\mathrm{ZnTe}: \mathrm{N}$ & ITO/AZO & $7.8 \%$ & {$[32]$} \\
\hline 6 & Univ. of S. Florida, 2009 & CSS & 650 & 425 & $\mathrm{Sb}_{2} \mathrm{Te}_{3} / \mathrm{Mo}$ & ITO & $6 \%$ & {$[44]$} \\
\hline 7 & *Univ. of Toledo, 2009 & MS & 260 & 387 & $\mathrm{Cu}: \mathrm{Au}$ & $\mathrm{AZO}$ & $10.5 \%$ & {$[34]$} \\
\hline 8 & *ETH Switzerland, 2009 & HVE & 300 & 420 & $\mathrm{Cu}: \mathrm{Au}$ & $\mathrm{AZO}$ & $12.4 \%$ & {$[28]$} \\
\hline 9 & *EMPA Switzerland, 2011 & - & - & - & - & - & $13.8 \%$ & [25] \\
\hline
\end{tabular}

* Polyimide substrate.

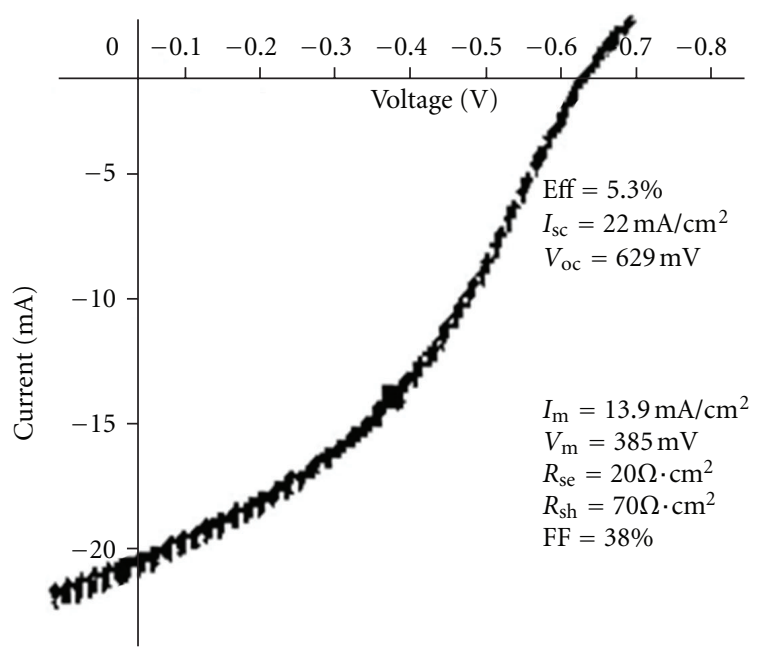

Figure 6: $I-V$ characteristics of the Mo/CdTe/CdS/ITO cell [8].

\section{Some Milestone Researches in Flexible CdTe Solar Cells}

The flexible CdTe solar cell has evolved through certain key researches achieved to its present status. These strategic researches are summarized in Table 1.

\section{Strategies for More Efficient Metal Substrate-Based Flexible Cells}

Based on the foregone discussion, it is important that some strategies are applied so that more efficient, cost-effective flexible solar cells based on metallic foil, are obtained. This section reviews some techniques that can be used to achieve these. Most of these have been successfully applied to glassbased modules.

Firstly, it is known that metallic foils can support only substrate solar cells, which have so far produced lower effi-

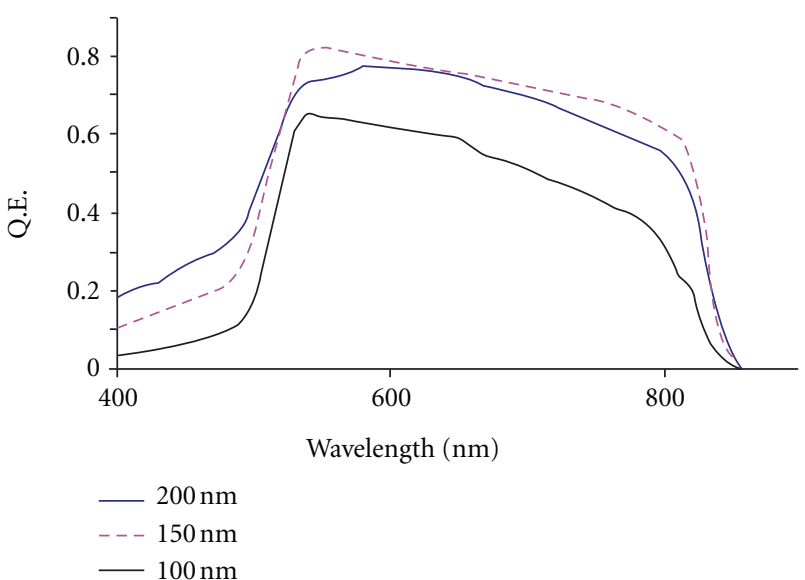

(a)

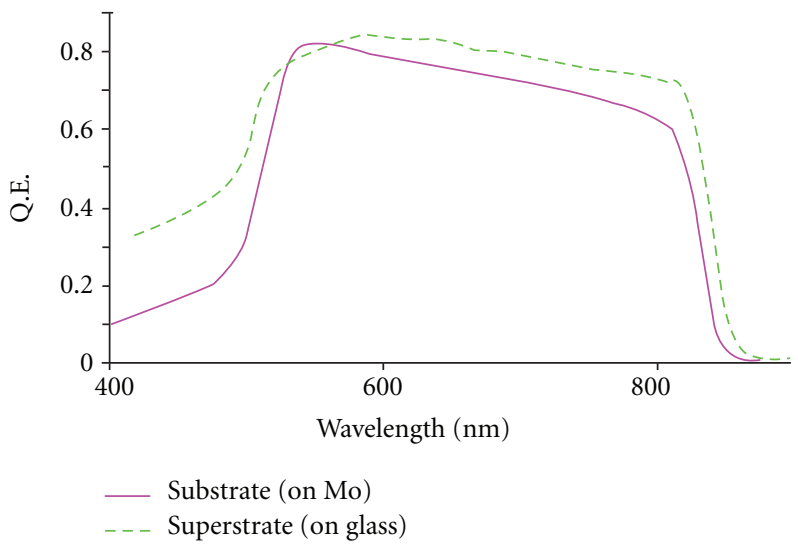

(b)

Figure 7: QE for cells (a) with various CdS thickness and (b) in substrate and superstrate [26].

ciency compared to superstrates. It therefore becomes imperative that the reasons that cause this lower efficiency are identified and minimized. These are hereby analyzed under various categories. 
5.1. Improvement Involving the CdS-CdTe Junction Formation. The first important property which differentiates substrate from superstrate is the issue of CdS-CdTe junction where its formation is crucial to the cell performance. The following are therefore important in fabrication of substrate cells:

(i) deposition of larger grain sized CdTe solar cells, in order to reduce the sulphur diffusion into the CdTe;

(ii) use of thinner CdS layer for higher spectral response is necessary, since in substrate cells, there is little interdiffusion at the CdSTe thus less effect on CdS thickness;

(iii) selection of suitable deposition methods and conditions for smoother CdTe films in order to reduce the effect of rough CdTe surface for CdS;

(iv) development of a good annealing process for optimized CdTeS interface layer.

\subsection{Improvement of Substrates}

(i) Though other metals have been used, Mo is still the most suitable for CdTe substrate due to its matching thermal expansion characteristics.

(ii) Development of new, appropriate buffer layers between metal substrate and CdTe layers to avoid diffusion.

(iii) Use of high-purity substrates are required to avoid impurity diffusion.

(iv) Use of smoother substrates should be emphasized in order to produce better films.

(v) Proper annealing optimization to minimize film delamination.

\subsection{Improvements of Back Contacts}

(i) New BSF layers and metallic interlayers between CdTe and substrates should be determined for better performance, in particular, materials which produced good results in glass substrates such as $\mathrm{ZnTe}, \mathrm{Sb}_{2} \mathrm{Te}_{3}$, $\mathrm{AS}_{2} \mathrm{Te}_{3}$, and $\mathrm{CuTe}$, need to be investigated for better ohmic back contacts.

(ii) Use of better doping techniques and materials to achieve higher carrier concentrations at the p-CdTe for better Ohmic contacts.

\subsection{Systematic Selection of Deposition Methods}

(i) While CSS produces large grained CdTe films, its high temperature requirement may affect the back contacting technique performed. Thus low temperature deposition techniques such as sputtering, HVE, and ED may be preferred.

(ii) ED method is a simple, cost-effective and industrially viable process, coupled with its low temperature requirements, making it a potentially viable method for flexible CdTe deposition on metallic foils. (iii) HVE has equally shown good promise, due to its relatively low temperature $\left(<300^{\circ} \mathrm{C}\right)$, with postdeposited grains sizes of up to $10 \mu \mathrm{m}$. This method has so far produced good performing flexible CdTe solar cells.

(iv) Sputtering has the advantage of low temperature process, but has limitation of stress induced by the ion bombardment. The method is easily adopted to industrial roll-to-roll production. Best substrate cell efficiency solar cells have been produced using this method. Thus, the method has good potentials in flexible CdTe solar cell manufacture.

\section{Conclusion}

Conventional CdTe solar cells have been deposited on glass substrates, making such modules heavy, rigid, and inflexible, coupled and with manufacture, transportation, and installation difficulties, and leading to higher production and installation costs. However, by replacing glass with flexible metallic foils, these problems could be reduced or eliminated, resulting in wider applications, portability, and availability of such simpler modules. Although polymerbased superstrate cells have produced efficiency close to that of glass, metal-based substrate cells can only be deposited in the substrate configuration, which is known to produce lower efficiency solar cells, but the technology is still attractive because of its roll-to-roll manufacturability. The reasons for the low efficiency include unfavorable CdS-CdTe junction formation, rough substrates, poor back contact between CdTe and metal foil, and appropriate choice of deposition methodology. By methodologically resolving these and other issues, it is believed that better performance flexible CdTe solar cells would become more competitive with their glass-based counterparts.

\section{Acknowledgments}

The authors wish to recognize the contribution of the Faculty of Engineering and Built Environment, Universiti Kebangsaan Malaysia (UKM), and Solar Energy Research Institute (SERI), Universiti Kebangsaan Malaysia for the assistance rendered through the research Grant UKM-KK-07FRGS0217-2010.

\section{References}

[1] B. M. Basol, "Electrodeposited CdTe and HgCdTe solar cells," Solar Cells, vol. 23, no. 1-2, pp. 69-88, 1988.

[2] X. Mathew, G. W. Thompson, V. P. Singh et al., "Development of CdTe thin films on flexible substrates-a review," Solar Energy Materials and Solar Cells, vol. 76, no. 3, pp. 293-303, 2003.

[3] First Solar Sets Record for CdTe Solar PV Efficiency, 2011, http://solarbuzz.com/industry-news/first-solar-sets-recordcdte-solar-pv-efficiency.

[4] S. M. Sze, Physics of Semiconductor Devices, Wiley Interscience, New York, NY, USA, 2nd edition, 1981.

[5] A. Seth, G. B. Lush, J. C. McClure, V. P. Singh, and D. Flood, "Growth and characterization of CdTe by close spaced 
sublimation on metal substrates," Solar Energy Materials and Solar Cells, vol. 59, no. 1, pp. 35-49, 1999.

[6] A. Romeo, M. Arnold, D. L. Batzner, H. Zogg, and A. N. Tiwari, "Development of high efficiency flexible CdTE solar cells," PV in Europe-From PV Technology to Energy Solutions, pp. 377-381, 2002.

[7] G. P. Hernández, X. Mathew, J. P. Enríquez et al., "Structural characterization of CdTe thin films developed on metallic substrates by close spaced sublimation," Journal of Materials Science, vol. 39, no. 4, pp. 1515-1518, 2004.

[8] V. P. Singh, J. C. McClure, G. B. Lush et al., "Thin film CdTe-CdS heterojunction solar cells on lightweight metal substrates," Solar Energy Materials and Solar Cells, vol. 59, no. 1, pp. 145-161, 1999.

[9] S. Chandramohan, R. Sathyamoorthy, S. Lalitha, and S. Senthilarasu, "Structural properties of CdTe thin films on different substrates," Solar Energy Materials and Solar Cells, vol. 90, no. 6, pp. 686-693, 2006.

[10] A. N. Tiwari, "Low Cost Flexible Solar cells: Prospects and challenges," 2006, http://www.europeanenergyfair.com/download_07/Session\%204_pv/Website_Tiwari.pdf.

[11] C. Ferekides, "Next generation CdTe technology substrate foilbased solar cells," in DOE Solar Energy Technologies Program Peer Review Technical Track, Denver, Colo, USA, 2009.

[12] A. N. Tiwari, A. Romeo, D. Baetzner, and H. Zogg, "Flexible CdTe solar cells on polymer films," Progress in Photovoltaics, vol. 9, no. 3, pp. 211-215, 2001.

[13] A. Romeo, D. L. Bätzner, H. Zogg, and A. N. Tiwari, "Potential of CdTe thin film solar cells for apace applications," in Proceedings of the 17th European Photovoltaic Conference and Exhibition, pp. 2183-2186, Munich, Germany, 2001.

[14] A. Romeo, D. L. Bätzner, H. Zogg, and A. N. Tiwari, "Influence of proton irradiation and development of flexible CdTe solar cells on polyimide," in Proceedings of the Materials Research Society Symposium, vol. 668, Materials Research Society, 2001.

[15] A. Romeo, A. Terheggen, M. Abou-Ras et al., "Development of thin-film $\mathrm{Cu}(\mathrm{In}, \mathrm{Ga}) \mathrm{Se} 2$ and CdTe solar cells," Progress in Photovoltaics, vol. 12, pp. 93-111, 2004.

[16] D. J. Flood, I. Weinberg et al., "Advanced solar cells for satellite power systems," NASA Technical Memorandum 106777, NASA, 1994.

[17] S. Chandramohan, R. Sathyamoorthy, P. Sudhagar et al., "Influence of SHI irradiation on the structure and surface topography of CdTe thin films on flexible substrate," Journal of Materials Science, vol. 18, no. 11, pp. 1093-1098, 2007.

[18] D. L. Bätzner, A. Romeo, M. Döbeli, K. Weinert, H. Zogg, and A. N. Tiwari, "High energy irradiation properties of CdTe/CdS solar cells," in Proceedings of the 29th IEEE Photovoltaic Specialists Conference, pp. 982-985, New Orleans, La, USA, May 2002.

[19] M. B. Schubert and J. H. Werner, "Flexible solar cells for clothing," Materials Today, vol. 9, no. 6, pp. 42-50, 2006.

[20] W. D. Hartmann, K. Steilmann, and A. Ullsperger, High-Tech Fashion, Heimdall, Germany, 2000.

[21] M. Pagliaro, R. Ciriminna, and G. Palmisano, "Flexible solar cells," ChemSusChem, vol. 1, no. 1, pp. 880-891, 2008.

[22] G. Khrypunov, A. Romeo, F. Kurdesau, D. L. Bätzner, H. Zogg, and A. N. Tiwari, "Recent developments in evaporated CdTe solar cells," Solar Energy Materials and Solar Cells, vol. 90, no. 6, pp. 664-677, 2006.

[23] A. Romeo, G. Khrypunov, F. Kurdesau et al., "High-efficiency flexible CdTe solar cells on polymer substrates," Solar Energy Materials and Solar Cells, vol. 90, no. 18-19, pp. 3407-3415, 2006.
[24] G. P. Hernández, A. S. Juarez, M. C. Resendiz, and X. Mathew, "Influence of the $\mathrm{Au}$ interlayer on the contact resistance and morphology of CdTe films deposited on molybdenum substrate," Solar Energy Materials and Solar Cells, vol. 90, no. 15, pp. 2289-2296, 2006.

[25] Efficiency Record Set for Flexible CdTe Solar Cell, 2011, http://www.photonics.com/Article.aspx?AID=47412.

[26] I. Matulionis, S. Han, J. A. Drayton, K. J. Price, and A. D. Compaan, "Cadmium telluride solar cells on molybdenum substrates," in Proceedings of the Materials Research Society Symposium, vol. 668, 2001.

[27] A. D. Compaan and V. Karpov, "The fabrication and physics of high-efficiency CdTe thin-film solar cells," Annual Technical Report, 2002.

[28] J. Perrenoud, S. Buecheler, and A. N. Tiwari, "Flexible CdTe solar cells and modules: challenges and prospects," in Thin Film Solar Technology, vol. 7409 of Proceedings of SPIE, 2009.

[29] W. Wangshen, X. Wang, G. Thompson, J. C. McClure, and V. Singh, "An investigation of $\mathrm{ZnO}-\mathrm{CdS}-\mathrm{CdTe}$ heterojunction solar cells on molybdenum substrates," in Proceedings of the 2nd World Photovoltaic Conference, pp. 1055-1058, Vienna, Austria, 1998.

[30] A. Seth, G. B. Lush, J. C. McClure, V. P. Singh, and D. Flood, "Growth and characterization of CdTe by close spaced sublimation on metal substrates," Solar Energy Materials and Solar Cells, vol. 59, no. 1, pp. 35-49, 1999.

[31] J. Drayton, A. Vasko, A. Gupta, and A. D. Compaan, "Magnetron sputtered CdTe solar cells on flexible substrates," in Proceedings of the 31st IEEE Photovoltaic Specialists Conference, pp. 406-409, January 2005.

[32] I. Matudionis, Superstrate and subsstrate type CdTe solar cells and monolithic integration of photovoltaic modules, Ph.D. thesis, University of Toledo, 2002.

[33] M. Fonrodona, J. Escarré, F. Villar et al., "PEN as substrate for new solar cell technologies," Solar Energy Materials and Solar Cells, vol. 89, no. 1, pp. 37-47, 2005.

[34] A. C. Vasko, Issues in the development of all-sputtered $\mathrm{ZnO} / \mathrm{CdS} / \mathrm{CdTe}$ flexible solar cells, Ph.D. thesis, University of Telodo, 2009.

[35] High Temperature-Embossed UPILEX Film UBE IndustriesAerospace Materials Specialty Chemicals and Products, 2006.

[36] UBE Industries Upilex datasheets, 2002.

[37] Du Pont Kapton datasheet 100HN Polyimide Film, http:// www.matweb.com/.

[38] X. Mathew, J. P. Enriquez, A. Romeo, and A. N. Tiwari, "CdTe/CdS solar cells on flexible substrates," Solar Energy, vol. 77, no. 6, pp. 831-838, 2004.

[39] Flexible CdTe Solar Cell Efficiency Record Due To Novel Polyimide Film, 2011, http://www.zimbio.com/Solar+cells/ articles/pX0ifyJf-Dv/Flexible+CdTe+Solar+Cell+Efficiency+ Record.

[40] X. Mathew, P. J. Sebastian, A. Sanchez, and J. Campos, "Structural and opto-electronic properties of electrodeposited CdTe on stainless steel foil," Solar Energy Materials and Solar Cells, vol. 59, no. 1, pp. 99-114, 1999.

[41] V. P. Singh and J. C. McClure, "Design issues in the fabrication of CdS-CdTe solar cells on molybdenum foil substrates," Solar Energy Materials and Solar Cells, vol. 76, no. 3, pp. 369-385, 2003.

[42] J. P. Enríquez, X. Mathew, G. P. Hernández et al., "CdTe/CdS Solar cells on flexible molybdenum substrates," Solar Energy Materials and Solar Cells, vol. 82, no. 1-2, pp. 307-314, 2004.

[43] H. Chavez, R. Santiesteban, J. C. Mcclure, and V. P. Singh, "Evaporated cadmium telluride films on steel foil substrates," Journal of Materials Science, vol. 6, no. 1, pp. 21-24, 1995. 
[44] D. R. Hodges, Development of CdTe thin film solar cells on flexible foil substrates, Ph.D. thesis, University of South Florida, 2009.

[45] P. D. Paulson and X. Mathew, "Spectroscopic ellipsometry investigation of optical and interface properties of CdTe films deposited on metal foils," Solar Energy Materials and Solar Cells, vol. 82, no. 1-2, pp. 279-290, 2004.

[46] A. Romeo, D. L. Bätzner, H. Zogg, and A. N. Tiwari, "A comparison of the vacuum evaporated CdTe for substrate and superstrate solar cells," in Proceedings of the 16th European Photovoltaic Solar Energy Conference, pp. 843-846, Glasgow, UK, 2000.

[47] G. P. Hernandez, X. Mathew, P. J. Enriquez, N. R. Mathews, and P. J. Sebastian, "Influence of the deposition potential on the structure and composition of the CdTe films electrodeposited on stainless steel substrates," Solar Energy Materials and Solar Cells, vol. 70, no. 3, pp. 269-275, 2001.

[48] X. Mathew, J. P. Enriquez, G. Casambias Segura et al., "Development of a substrate configuration $\mathrm{CdTe} / \mathrm{CdS}$ solar cell on flexible molybdenum substrate," in Proceedings of the 31st IEEE Photovoltaic Specialists Conference, pp. 434-436, 2005.

[49] N. Amin, M. A. Matin, M. M. Aliyu, M. A. Alghoul, M. R. Karim, and K. Sopian, "Prospects of back surface field effect in ultra-thin high-efficiency CdS/CdTe solar cells from numerical modeling," International Journal of Photoenergy, vol. 2010, Article ID 578580, 8 pages, 2010.

[50] N. Amin, Study of high efficiency CdTe ultra-thin film solar cells by CSS, Ph.D. thesis, Tokyo Institute of Technology, Tokyo, Japan, 2000.

[51] T. Markvart and L. Castaner, Solar Cells: Materials, Manufacture and Operation, Oxford, UK, Elservier, 2006.

[52] J. P. Enríquez and X. Mathew, "The effect of annealing on the structure of CdTe films electro-deposited on metallic substrates," Journal of Crystal Growth, vol. 259, no. 3, pp. 215222,2003

[53] L. A. Kosyachenko, X. Mathew, V. V. Motushchuk, and V. M. Sklyarchuk, "Electrical properties of electrodeposited CdTe photovoltaic devices on metallic substrates: study using small area Au-CdTe contacts," Solar Energy, vol. 80, no. 2, pp. 148 155, 2006.

[54] M. P. R. Panicker, M. Knaster, and F. A. Kroger, "Cathodic deposition of CdTe from aqueous electrolytes," Journal of the Electrochemical Society, vol. 125, no. 4, pp. 566-572, 1978.

[55] F. R. Bunshah, Handbook of Deposition Technologies for Films and Coatings- Science, Technology and Applications, Noyes Publications, NJ, USA, 1994.

[56] B. M. Basol, "High-efficiency electroplated heterojunction solar cell," Journal of Applied Physics, vol. 55, no. 2, pp. 601603, 1984.

[57] G. S. Khrypunov, E. P. Chernykh, N. A. Kovtun, and E. K. Belonogov, "Flexible solar cells based on cadmium sulfide and telluride," Semiconductors, vol. 43, no. 8, pp. 1046-1051, 2009. 


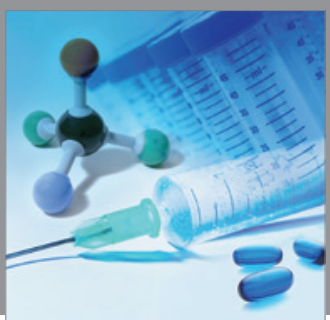

International Journal of

Medicinal Chemistry

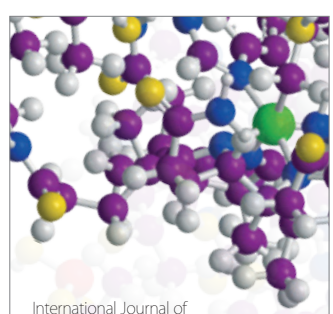

Carbohydrate Chemistry

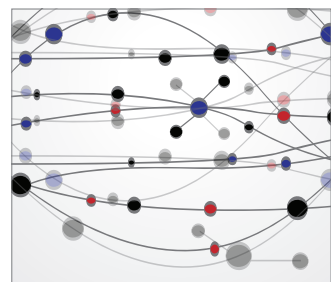

The Scientific World Journal
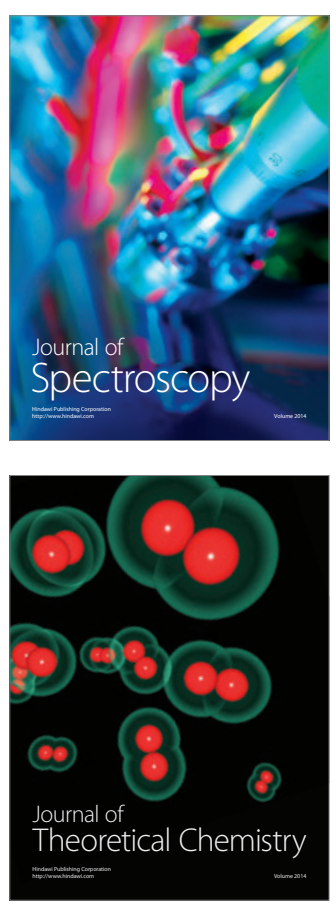
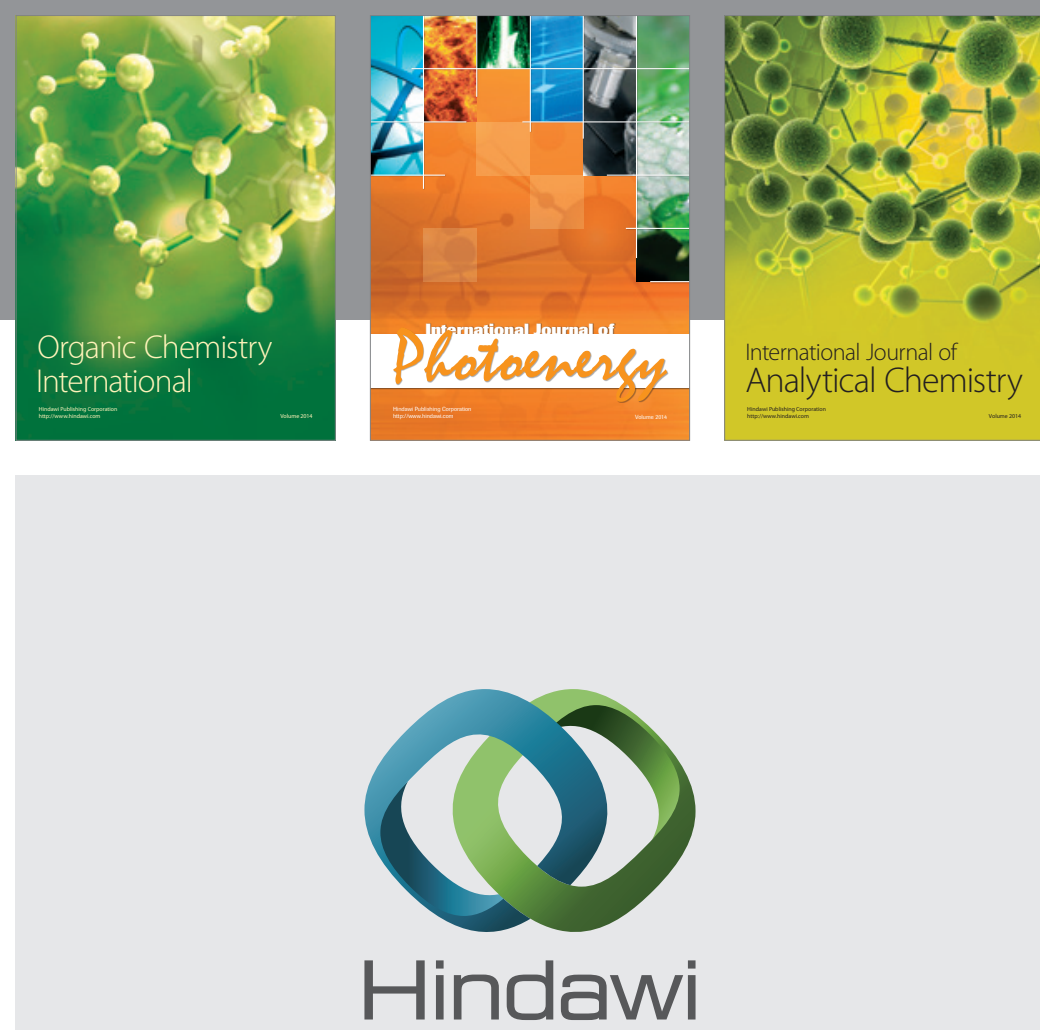

Submit your manuscripts at

http://www.hindawi.com
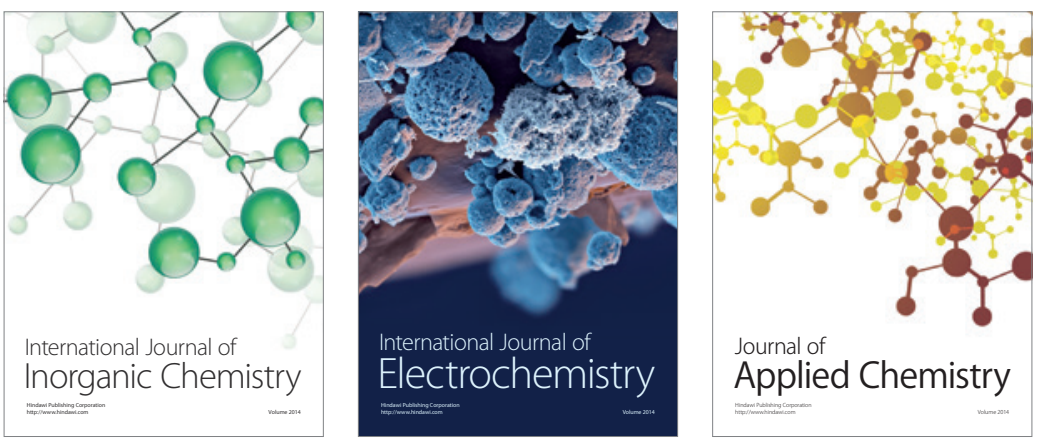

Journal of

Applied Chemistry
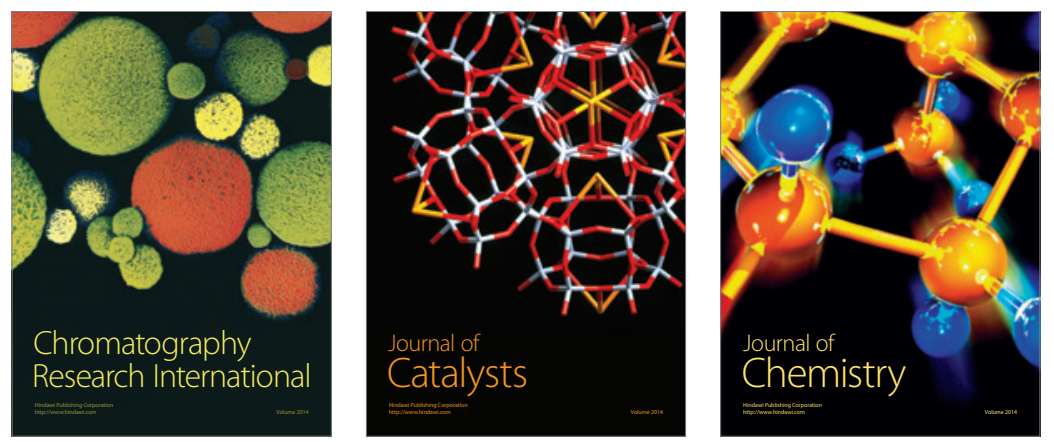
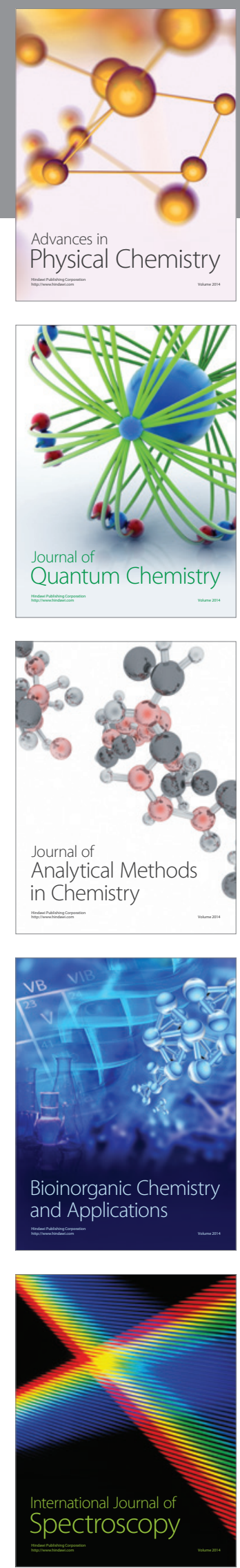